\title{
Effect of Weed Management Practices on Weed Dynamics, Yield, Quality Parameters and Economics of Organic Bhendi
}

\author{
R. Gopi Krishna ${ }^{1}$, Somasundaram ${ }^{2}$, E.Ganesan ${ }^{2}$, K. and A.Bharani ${ }^{2}$ \\ 'Department of Agronomy, ${ }^{2}$ Department of Sustainable Organic Agriculture, \\ Tamil Nadu Agricultural University, Coimbatore - 641003
}

\begin{abstract}
A field experiment was conducted at Eastern Block Farm of Tamil Nadu Agricultural University, Coimbatore, to evaluate the weed dynamics, fruit yield and economics as influenced by different weed management practices on organic bhendi during kharif 2017. The treatment consists of Stale Seed Bed (SSB) technique with 25 per cent reduced spacing along with mulching of crop residues@ $5 \mathrm{t} \mathrm{ha}^{-1}$, weeds as mulch@ $5 \mathrm{t} \mathrm{ha}^{-1}$, incorporation of de-oiled neem cake @ $2.5 \mathrm{t} \mathrm{ha}^{-1}$, deep ploughing and mulching with mango leaves @ $5 \mathrm{t} \mathrm{ha}^{-1}$, multi-varietal seed technique, intercropping with cowpea, hand weeding twice, one hand weeding along with 25 per cent aqueous eucalyptus leaf extract spray as post emergence on 30 DAS and unweeded control. SSB technique with 25 per cent reduced spacing along with mulching of crop residues @ $5 \mathrm{t} \mathrm{ha}^{-1}$ was very effective in controlling weeds and recorded lower weed density, weed dry weight and higher fruit yield $\left(29.7 \mathrm{t} \mathrm{ha}^{-1}\right)$. It was followed by intercropping with cowpea and in-situ incorporation on 45 DAS and locally available weeds as mulch @ $5 \mathrm{t} \mathrm{ha}^{-1}$ along with one hand weeding on 45 DAS.
\end{abstract}

Key words: Organic bhendi, Weed management, Stale seed bed, Weed density and Dry weight.

Bhendi (Abelmoschus esculentus (L.) Moench) an annual herbaceous plant belongs to malvaceae family is one of the most important warm season vegetable crops grown widely in tropical and subtropical regions of the world. It is the fifth important vegetable crop in India cultivated in 0.51 million hectare with an production of 5.85 million tonnes and productivity of $11.45 \mathrm{t} \mathrm{ha}^{-1}$, occupies 70 per cent of the world production (National Horticultural Board, 2016). It is commonly known as bhindi, okra, lady's finger and regarded queen of vegetables due to its high nutritional value rich in vitamins, minerals and dietary fibres which has zero trans-fat and low calorific value. Bhendi is susceptible to weeds at early stage of crop growth accounts 70 per cent yield loss due to high infestation by grasses and broad leaved weeds (Singh and Tripati, 1990). The critical weed free period was found to be between 2 and 6 weeks, which needs frequent weed checks; increases cost of cultivation was found uneconomical (Patel et al., 2004). Hence the present study was undertaken to develop an effective, economical weed management practice for sustainable production of organically cultivated bhendi.

\section{Material and Methods}

The experiment was conducted at Eastern Block Farm of Tamil Nadu Agricultural University, Coimbatore during July to November, 2017. The experimental site located in the western agro climatic zone of Tamil Nadu at $1 \mathrm{lo} \mathrm{N}$ latitude, $77^{\circ} \mathrm{E}$ longitude and at an altitude of $426.72 \mathrm{~m}$ above mean sea level. Soil of the experimental site was clay loam with a $\mathrm{pH}$

*Corresponding author's email: gopikrishna1194@gmail.com
8.3, low in organic carbon $(0.38 \%)$ and medium in available nitrogen (336 kg ha-1), medium in available phosphorus (17.5 $\left.\mathrm{kg} \mathrm{ha}^{-1}\right)$ and high in available potassium (459 kg ha-1). Experiment was laid out in randomized blocks design with three replications and nine treatments viz., stale seed bed technique with 25 per cent reduced spacing along with mulching of crop residues @ $5 \mathrm{t} \mathrm{ha}^{-1}$; locally available weeds as mulch@ $5 \mathrm{t} \mathrm{ha}^{-1}$ with a hand weeding on 45 DAS; incorporation of de-oiled neem cake @ $2.5 \mathrm{t} \mathrm{ha}^{-1}$ of 15 days before sowing with a hand weeding on 45 DAS; deep ploughing and mulching with dried mango leaves @ $5 \mathrm{t} \mathrm{ha}^{-1}$ with one hand weeding on 45 DAS; Multi-varietal seed technique and in situ incorporation on 45 DAS; inter-cropping with cowpea and in situ incorporation on 45 DAS; hand weeding twice on 20 and 45 DAS; one hand weeding on 20 DAS and spraying of 25 per cent aqueous leaf extract of eucalyptus as post emergence on 30 DAS and unweeded control. Organic amendments of well decomposed FYM (25 t ha $\left.{ }^{-1}\right)$, vermicompost (1 t ha $^{-1}$ ) and 3 per cent panchagavya spray were used as nutrient source. Stale seed bed is based on the principle of flushing out germinable weed seeds prior to the planting of the crop by light harrowing or hoeing, ridges and furrows are formed by reducing inter row spacing to 25 per cent. Different organic mulches viz., dried sunflower stalk residues, locally available weeds were collected shade dried and dried mango leaves were applied on 10 DAS to the respective treatments. Observations on weed density were taken by using quadrat $(0.5 \mathrm{~m} \times 0.5 \mathrm{~m})$ and weed control efficiency as suggested by Burnside and Wicks (1965) and Mani et al. (1973). Quality parameters such as ascorbic 
acid and acidity content of fruits were analyzed as per the method suggested by A.O.A.C (1975). The cost of cultivation, gross return, net return and benefit cost ratio were calculated on the basis of prevailing market price of different inputs and outputs. The observed data on weeds [square root transformation ( ) and crops were statistically analyzed based on the procedure given by Gomez and Gomez (1984)

\section{Results and Discussion}

\section{Weed flora}

Weed flora of the experimental field was dominated by the BLW $>$ Grasses $>$ Sedges consisted of six, one and ten species, respectively. The pre-dominant weed species of grasses, sedges and broad leaved weeds such as Cynodon dactylon, Cyperus rotundus

Table 1. Effect of weed management practices on weed dynamics in organic bhendi

\begin{tabular}{|c|c|c|c|c|c|c|c|}
\hline \multirow{2}{*}{\multicolumn{2}{|c|}{ Treatments }} & \multicolumn{3}{|c|}{ Weed Density (No. $\mathrm{m}^{-2}$ ) } & \multicolumn{3}{|c|}{ Weed Dry Weight $\left(\mathrm{g} \mathrm{m}^{-2}\right)$} \\
\hline & & \multirow{2}{*}{$\begin{array}{c}45 \text { DAS } \\
3.07 \\
(8.91)\end{array}$} & \multirow{2}{*}{$\begin{array}{c}15 \text { DAS } \\
4.57 \\
(20.42)\end{array}$} & \multirow{2}{*}{$\begin{array}{c}30 \text { DAS } \\
5.27 \\
(27.32)\end{array}$} & \multirow{2}{*}{$\begin{array}{c}45 \text { DAS } \\
5.04 \\
(24.90)\end{array}$} & \multirow{2}{*}{$\begin{array}{c}15 \text { DAS } \\
6.42 \\
(40.77)\end{array}$} & \multirow{2}{*}{$\begin{array}{c}30 \text { DAS } \\
8.89 \\
(78.44)\end{array}$} \\
\hline $\mathrm{T}_{1}$ & $\begin{array}{l}\text { SSB technique }+25 \text { per cent reduced spacing }+ \text { mulching } \\
\text { with crop residues } @ 5 \text { t ha }^{-1}\end{array}$ & & & & & & \\
\hline $\mathrm{T}_{2}$ & $\begin{array}{l}\text { Locally available weeds as mulch @ } 5 \mathrm{t} \mathrm{ha}^{-1}+\text { one } \mathrm{HW} \text { on } \\
45 \text { DAS }\end{array}$ & $\begin{array}{c}5.55 \\
(30.34)\end{array}$ & $\begin{array}{c}6.78 \\
(45.47)\end{array}$ & $\begin{array}{c}8.22 \\
(67.01)\end{array}$ & $\begin{array}{c}7.30 \\
(52.76)\end{array}$ & $\begin{array}{c}8.75 \\
(76.12)\end{array}$ & $\begin{array}{c}11.03 \\
(121.09)\end{array}$ \\
\hline $\mathrm{T}_{4}$ & $\begin{array}{l}\text { Deep ploughing and mulching with dried mango leaves @ } 5 \\
\text { t ha-1 + one HW on } 45 \text { DAS }\end{array}$ & $\begin{array}{c}6.87 \\
(46.75)\end{array}$ & $\begin{array}{c}11.07 \\
(122.12)\end{array}$ & $\begin{array}{c}10.15 \\
(102.61)\end{array}$ & $\begin{array}{c}9.79 \\
(95.36)\end{array}$ & $\begin{array}{c}15.76 \\
(248.00)\end{array}$ & $\begin{array}{c}13.05 \\
(169.92)\end{array}$ \\
\hline $\mathrm{T}_{5}$ & $\begin{array}{l}\text { Multi-varietal seed technique and in situ incorporation on } \\
45 \text { DAS }\end{array}$ & $\begin{array}{c}7.93 \\
(62.34)\end{array}$ & $\begin{array}{c}12.20 \\
(148.32)\end{array}$ & $\begin{array}{c}14.34 \\
(205.11)\end{array}$ & $\begin{array}{c}10.39 \\
(107.39)\end{array}$ & $\begin{array}{c}16.69 \\
(278.06)\end{array}$ & $\begin{array}{c}18.63 \\
(346.40)\end{array}$ \\
\hline $\mathrm{T}_{8}$ & $\begin{array}{l}\text { One HW on } 20 \text { DAS + Spraying } 25 \text { per cent aqueous leaf } \\
\text { extract of eucalyptus as POE on } 30 \text { DAS }\end{array}$ & $\begin{array}{c}10.51 \\
(109.92)\end{array}$ & $\begin{array}{c}8.54 \\
(72.43)\end{array}$ & $\begin{array}{c}9.47 \\
(89.21)\end{array}$ & $\begin{array}{c}13.48 \\
(181.21)\end{array}$ & $\begin{array}{c}10.33 \\
(106.23)\end{array}$ & $\begin{array}{c}13.11 \\
(171.28)\end{array}$ \\
\hline $\mathrm{T}_{9}$ & Un weeded control & $\begin{array}{c}10.57 \\
(111.30)\end{array}$ & $\begin{array}{c}15.36 \\
(235.48)\end{array}$ & $\begin{array}{c}16.84 \\
(282.99)\end{array}$ & $\begin{array}{c}13.59 \\
(184.19)\end{array}$ & $\begin{array}{c}19.95 \\
(397.41)\end{array}$ & $\begin{array}{c}24.80 \\
(614.77)\end{array}$ \\
\hline SE & & 0.53 & 0.49 & 0.68 & 0.51 & 0.64 & 0.77 \\
\hline CD & $P=0.05)$ & 1.12 & 1.04 & 1.45 & 1.09 & 1.36 & 1.64 \\
\hline
\end{tabular}

Figures in parenthesis are original values; data subjected to square root transformation ( )

SSB - Stale Seed Bed, DAS - Days After Sowing, HW - Hand Weeding, POE - Post Emergence

and Trianthema portulacastrum, respectively were observed. Similar broad spectrum of weed flora and pre-dominant weeds on bhendi were reported by Srinivasan and Veeraragavathatham (1999).

\section{Weed density}

At all the stages, maximum number of weeds was recorded under unweeded control (Table. 1).

\section{Table 2. Effect of weed management practices on total weed control efficiency (\%) in organic bhendi}

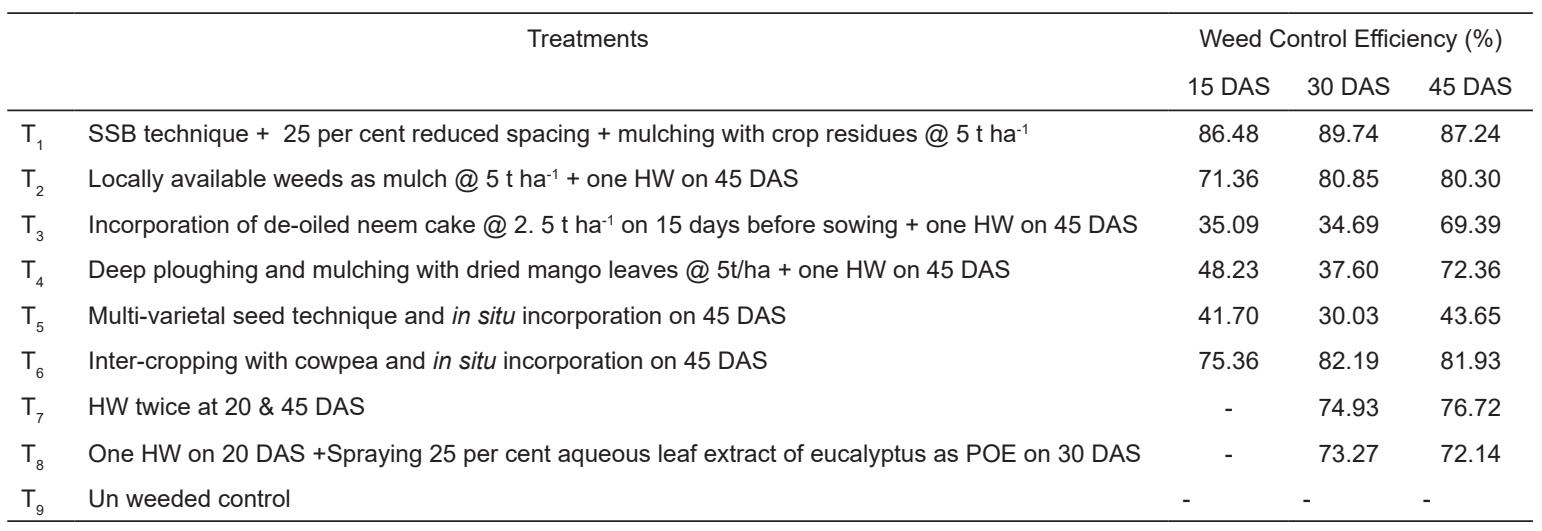

Data not statistically analyzed; SSB - Stale Seed Bed, DAS - Days after sowing, HW - Hand weeding, POE - Post emergence.

Stale seed bed technique with 25 per cent reduced spacing along with mulching of crop residues @ $5 \mathrm{t}$ ha ${ }^{-1}$ significantly reduced weed density $(3.03,4.57$ and $5.27 \mathrm{No}^{-2}$ ) at 15,30 and 45 DAS was primarily due to reduced weed seed bank in the shallow layer of soil, allelopathy of sunflower, which reduced weed pressure on crop. Similar findings were reported by Leather (1987). The effectiveness of stale seed bed to achieve weed control in bhendi has been reported by Ameena et al. (2013). 
Table 3. Effect of weed management practices on yield and economics of organic bhendi

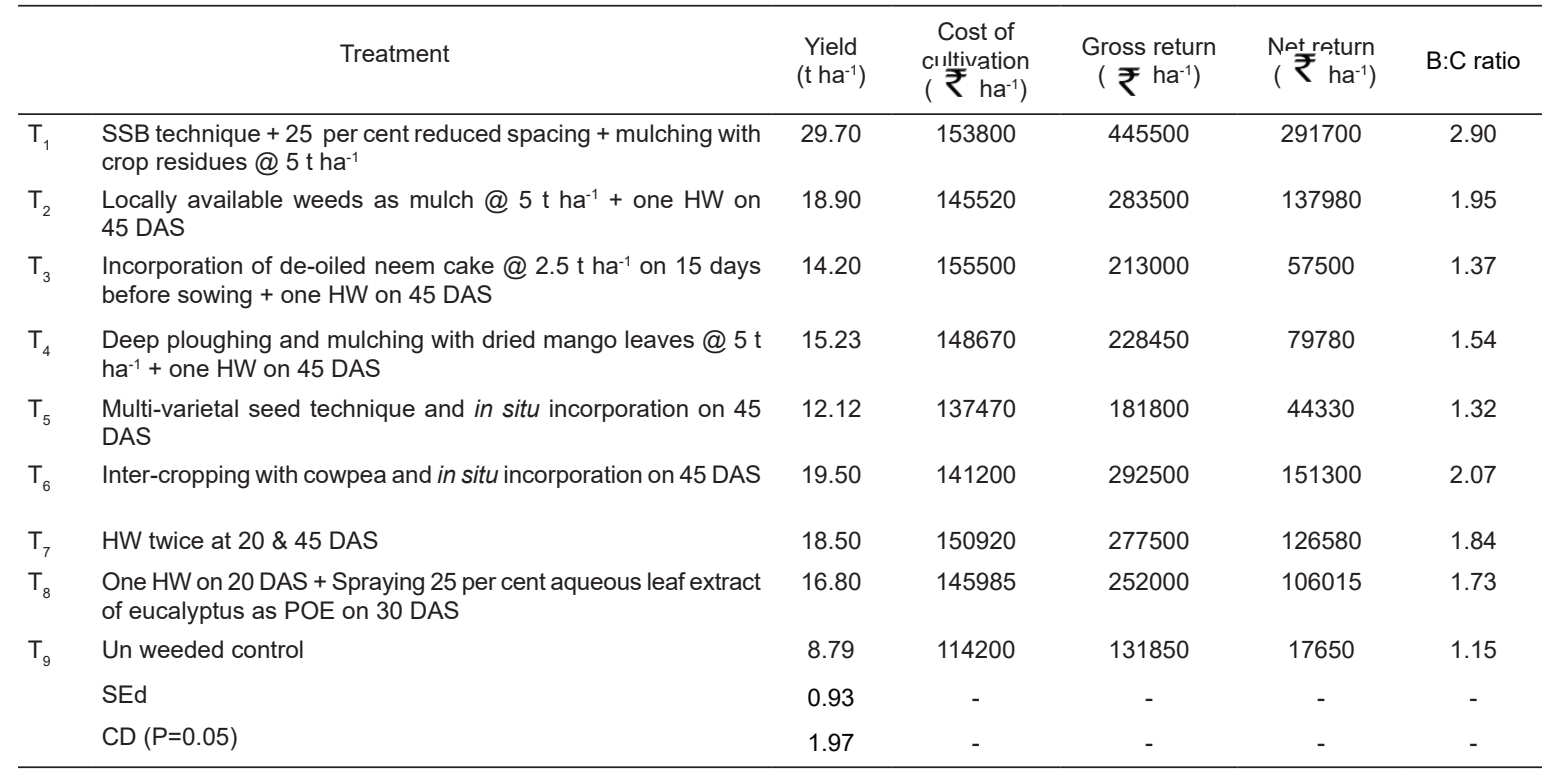

SSB - Stale Seed Bed, DAS - Days After Sowing, HW - Hand Weeding, POE - Post Emergence.

\section{Weed dry weight}

The results revealed (Table 1) that stale seed bed technique with 25 per cent reduced spacing along with mulching of crop residues @ $5 \mathrm{t} \mathrm{ha}^{-1}$ significantly reduced the drymatter which depicted the density of weeds to lower levels $(5.04,6.42$

Table 4. Effect of organic weed management practices on quality parameters of organic bhendi

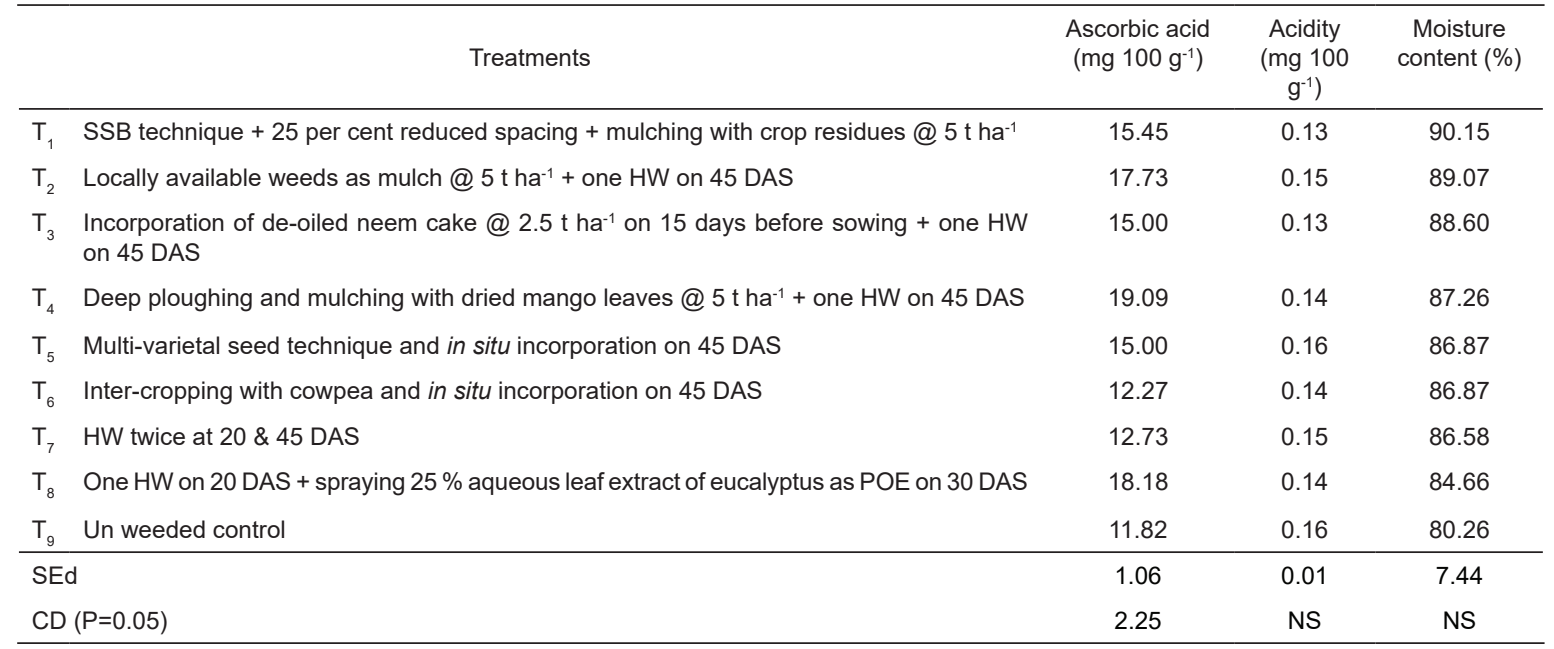

SSB - Stale Seed Bed, DAS - Days After Sowing, HW - Hand Weeding, POE - Post Emergence.

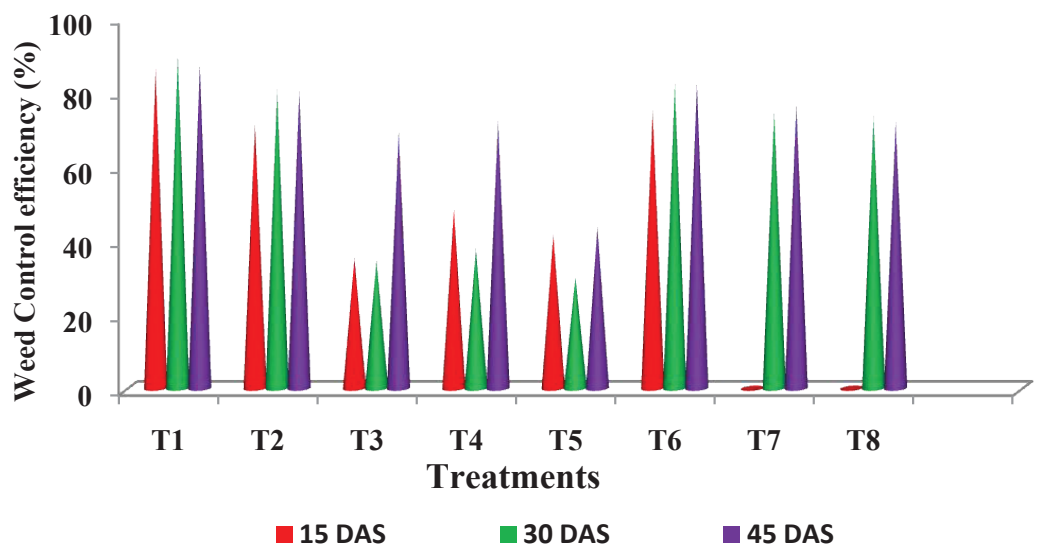

Fig. 1. Effect of weed management practices on total weed control efficiency of organic bhendi 
and $8.89 \mathrm{~g} \mathrm{~m}^{-2}$ ) at different stages (15, 30 and 45 DAS) of observation, which was followed by inter-cropping with cowpea and in situ incorporation on 45 DAS, locally available weeds as mulch @ 5 t ha $^{-1}$ along with one hand weeding on 45 DAS. Stale seed bed might have depleted weed seed bank reserve, mulching
25 per cent reduced spacing along with mulching of crop residues @ $5 \mathrm{t} \mathrm{ha}^{-1}$ registered high net return of ₹ 291700 ha $^{-1}$ and benefit cost ratio of 2.90 were found to be more economical than conventional hand weeding at 20 and 45 DAS. The cost effectiveness of stale seed bed to achieve to weed control in bhendi

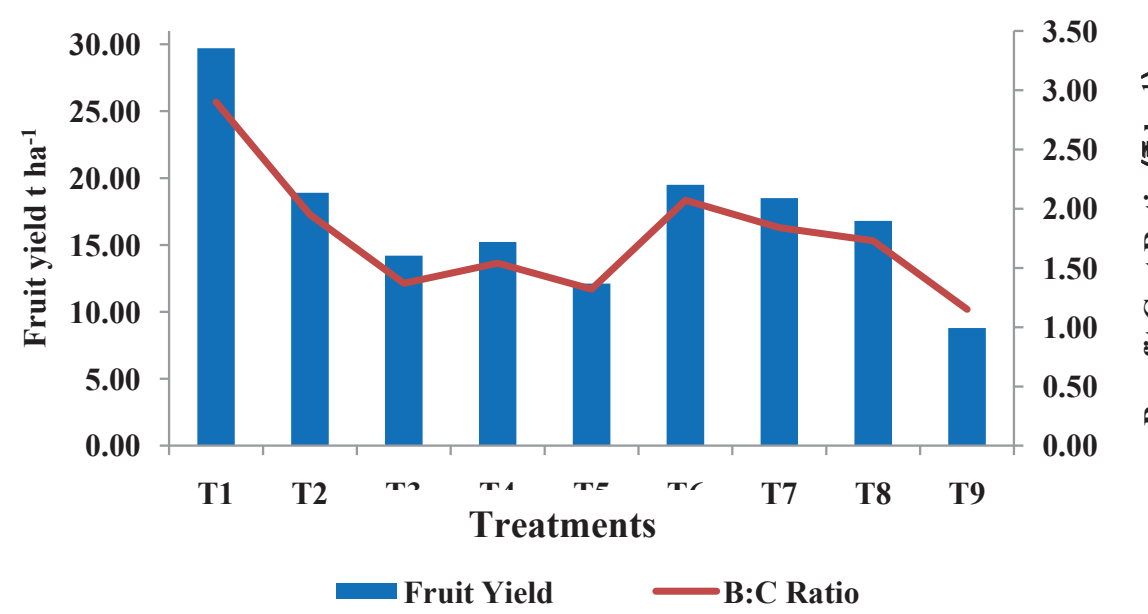

Fig. 2. Effect of weed management practices on fruit yield and economics of organic bhendi

hampered weed growth as a physical barrier and limited light transmission below mulches, conserved soil moisture. The results are in confirmation with the findings of Azhar Mahmood et al. (2016). Significantly higher weed dry weight was recorded in unweeded control (Singh et al., 1982).

\section{Weed control efficiency}

The different weed management practices exerted influence on weed control efficiency assessed at 15, 30 and 45 DAS (Table. 2 \& Fig. 1). Stale seed bed with 25 per cent reduced spacing along with crop residue mulch @ $5 \mathrm{t} \mathrm{ha}^{-1}$ recorded higher weed control efficiency of 85 per cent at all stages of crop growth may be due to suppressed weed emergence in the less inter space availability by altered plant population lead to less competition from the weeds for growth resources on the field. These findings are in line with the results by Sheela et al. (2007) and lyabaga et al. (2012).

\section{Fruit Yield}

Stale seed bed technique with 25 per cent reduced spacing along with mulching of crop residues @ $5 \mathrm{t} \mathrm{ha}^{-1}$ registered higher fruit yield of $29.7 \mathrm{t} \mathrm{ha}^{-1}$ (Table. 3 \& Fig. 2). It was followed by intercropping with cowpea and in situ incorporation on 45 DAS was very in effective in suppressing weeds recorded higher weed control efficiency at critical crop-weed competition period and at later stages. The advantage of stale seed practice on weed control and yield increase by reduced inter-row spacing 25 per cent was supported by Sheela et al. (2007) and Morwal and Patel (2017).

\section{Economics}

The results (Table. 3 \& Fig. 2 ) of the investigation clearly indicated that stale seed bed technique with and direct seeded rice was reported by Ameena et al. (2013) and John and Mathew (2001), respectively.

\section{Quality parameters}

The different organic weed management practices exerted significant influence on quality parameters (Table. 4). The ascorbic acid content was higher (19.09 $\mathrm{mg} 100 \mathrm{~g} \mathrm{~g}^{-1}$ ) in deep ploughing and mulching with dried mango leaves @ 5 t ha $^{-1}$ along with one hand weeding on 45 DAS might be due to the effect of high potassium content in mango leaves which enhanced the ascorbic acid content of bhendi fruits. These results are in corroboration with the findings of Dutta and Majumder (2009) in Guava. However, the acidity content and moisture per cent of fruits was not significantly influenced by different weed management practices in bhendi grown organically.

\section{Conclusion}

Among the different weed management practices studied stale seed bed technique with 25 per cent reduced spacing along with mulching of crop residues @ 5 t ha $^{-1}$ effectively controlled broad spectrum weeds and recorded higher yield and economic returns.

\section{References}

A.O.A.C. (1975). Official methods of analysis. Association of official analytical chemists, Washington, D.C., U.S.A.

Ameena, M., V.L. Geetha Kumari and Sansamma George. 2013. Control of purple nutsedge in okra through integrated management. Indian J. Weed Sci., 45(1): 51-54.

Azhar Mahmood, Muhammad Zahid Ihsan, Abdul Khaliq, Saddam Hussain, Zahid Ata Cheema, Muhammad Naeem, Ihsanullah Daur, Hafiz Athar Hussain and Fahad Alghabari. 2016. Crop Residues Mulch as Organic Weed Management Strategy in Maize. CSAWAC 44 (3): 219-324. 
Burnside, O.C. and G.A. Wicks. 1965. Effects of herbicide and cultivation treatments on yield components of dryland sorghum in Nebraska. Agron. J., 57(1): 21-24.

Dutta, P. and D. Majumder. 2009. Effect of mulching on post harvest quality of guava cv. L-49 grown in red and laterite tract of West Bengal. Adv. Hort. Sci., 23 : 175-78.

Gerald R. Leather. 1987. Weed control using allelopathic sunflowers and herbicide. Plant and Soil. 98: 17-23.

Gomez, K.A. and Gomez, A.A. 1984. Statistical procedure for agricultural research. John Wiley and Sons, New York. p. 680.

lyagba, A.G., B.A. Onuegbu and A.E. Ibe. 2012. Growth and Yield Response of Okra (Abelmoschus esculentus L.) Varieties to Weed Interference in South-Eastern Nigeria. Global J. Sci. Front. Res., 12(7): 23-31.

John, P.S. and R. Mathew 2001. Stale seedbed an alternate technology for pre-planting to achieve total weed control in direct seeded low land rice. International Rice Research Notes. 26: 67-68.

Mani, V.S., M.L. Mala, K.C. Gautam and Bhagavandas. 1973. Weed killing chemicals in potato cultivation. Indian Fmg., 23(1): 17-18.
Morwal, B.R. and M.C. Patel. 2017. Growth and Yield of Okra (Abelmoschus esculentus L) as Affected by Date of Sowing and Spacing under north Gujarat Condition. J. Krishi Vigyan. 6(1) : 93-96.

National Horticultural Board, 2016. Deparment of Agriculture Cooperation \& Farmers Welfare.

Patel, R.B., B.D Patel., M.I Meisuriya and V.J Patel. 2004. Effect of Methods of Herbicide Application on Weeds and Okra. Indian J. Weed Sci., 36 (3\&4) : 304-305.

Sheela, K.R., C.Nandakumar and R.Pushpakumari. 2007. Integrated weed management in bhindi (Abelmoschus esculentus L.). Acta Horticulturae., 752: 549-551.

Singh, G and S.S. Tripati. 1990. Effect of herbicides on okra (Abelmoschus esculentus L.) and associated weeds. In: Biennial Conference Indian Society of Weed Science, held at JNKVV, Jabalpur, March 4-5, 1990. P.127.

Singh, G., V.M. Bhan and S.S. Tripati. 1982. Weed control in okra (Abelmoschus esculentus L.). Indian J. Weed Sci., 14(1): 19-23.

Srinivasan, K and D. Veeraragavathatham. 1999. Studies on weed management in bhendi. Pestology. 23(4): 18-20.

Received : November 14, 2017; Revised : December 02, 2017; Accepted : December 28, 2017 